\title{
Second-Hand Faces: Aesthetic Surgery
}

That none may complain for want of timely Notice; Be it known to all men, by these presents, that this summer, at Temple-Oge, there will be a vast collection of fair hands, brilliant eyes, rosy cheeks, nimble tongues, ivory teeth, ruby lips, dimpled chins, high fronts, long necks; together with snowy breasts, handsome legs, and other valuable commodities, which, for weighty reasons, are determined to be concealed 'till the merchandizes before-mentioned are first disposed of and sold: There will be large quantities of kind glances, studied courtesies, languishing looks, sighs piping hot from the heart, and scornful sneers, that are only copies of the countenance; likewise ogles of all kinds, from a side leer to a full stare. ... And, that people, even in the most forlorn of circumstances, may not fail of proper accommodations, special care is intended to be taken, that there shall, likewise, be some second-hand faces, stale reputations, and broken constitutions, for the use and behoof of battered beaux, maimed debauchees, old batchelors, and other helpless persons, who have not money, or merit, enough to supply themselves more conveniently. ${ }^{\mathrm{I}}$

Purposely or otherwise, most early modern surgical interventions left their mark. The aesthetic results of mastectomy and amputation were profound, but more or less readily concealed by clothing. Childhood castration, as we have seen, created bodies which were profoundly aesthetically different and had a sexual value to match. Surgery on the face, however, posed unique challenges. As the above passage from the Universal Weekly Pamphlet makes clear, one's face could be one's fortune in the early modern marriage market, particularly for women. The face was not only the site of much sensory perception; it was also something to be itemised and anatomised, assessed and found wanting. It was a mark of, and criterion for, social and

I Eustace Budgell, ed., 'Notice of a Sale of Beauties, at Temple-Oge.', Bee, or Universal Weekly Pamphlet Revived, May 1733-June I733 2:17 (I6 June 1733): 738-40. 
economic capital. Beauty and agreeableness might, as this author suggested, be feigned, with 'studied courtesies' in which one's face was an instrument of deception; faces supplied only imperfect clues to the more 'valuable commodities' of virginity and fertility. However, faces also gave the game away, revealing the true characters of 'battered beaux' and 'maimed debauchees'.

This chapter examines the topic of those 'second-hand faces' which were, by one means or another, medically 'put on' - the result of prostheses, elaborate dentistry, or ground-breaking surgery. The potential of medicine to change appearances in this way once again raised the question of whether the body was 'me' or 'mine', subject or object. Did one own a face as one owned an item of clothing, to be augmented or transformed at will? Or was the face an intrinsic part of selfhood, such that changes to one's countenance were changes to one's very identity? A series of surprisingly bold innovations in facial prosthetics and surgery brought these questions to the fore for early modern audiences. The implantation of human teeth from one mouth to another, or the use of human teeth in dentures, might be viewed as forward-thinking or as exploitation. Meanwhile, allografting - the transfer of flesh from one body to another fired the imagination of satirists and scientists alike. In each instance of remaking the face, questions of bodily integrity and morality, the personal and social significance of the face, loomed large. ${ }^{2}$

\section{Saving Face}

If the face was important in early modern culture, it was also imperilled. Longstanding dangers to the face remained, including accidents resulting from handling livestock and horses, hazards from dangerous manual trades, and diseases such as cancers and syphilis. Added to these, the prevalence of armed conflict, and the nature of that conflict, inevitably produced a large number of serious facial injuries. Charles Carlton, for instance, claims that during the reign of Elizabeth I, around 55 per cent of all men aged between eighteen and thirty-nine would have served in the armed forces in one form or another. ${ }^{3}$ In the Nine Years War (I688-97),

\footnotetext{
${ }^{2}$ Certain material in this chapter is also treated in Emily Cock, Rhinoplasty and the Nose in Early Modern British Medicine and Culture (Manchester: Manchester University Press, 2019), which was published as final editing of this book was taking place. I have tried to provide references to Rhinoplasty and the Nose where it is appropriate; our respective works on this subject may be read as two ways of approaching the same problem.

3 Charles Carlton, This Seat of Mars: War and the British Isles, $1485-1746$ (New Haven: Yale University Press, 20II), p. 37.
} 
one in seven Englishmen served in the military. ${ }^{4}$ During long campaigns, these men were exposed to infectious disease and loss of extremities from frostbite, as well as from traditional close combat. They were also, more than ever, vulnerable to firearms and artillery. Cannon posed a particular threat when aimed at ships, where they produced shrapnel and could trigger devastating fires and explosions. The 'weight, softness, and slow trajectory' of musket balls could easily eviscerate their targets. ${ }^{5}$ Moreover, such wounds were particularly likely to become gangrenous, as fragments of cloth, dirt, and wood were carried deep into the flesh. It is unsurprising, therefore, that numerous eminent surgeons included detailed instructions for facial surgery and prostheses in their textbooks. Most remarkable among these was Ambroise Parés Workes, in which he suggested modes of restoring the ears, eyes, nose, and soft palate among other parts of the face. As a military surgeon, he had clearly encountered many such cases of catastrophic but survivable damage.

The first duty of facial prostheses was, wherever possible, to restore the function of the damaged part. More than any other contemporary surgeon, Paré supplied innovative methods of doing just that. For instance, he prescribed a remedy for holes in the palate which he hoped would allow the afflicted person to eat and speak. The patient was to put into their mouth a slightly dished piece of gold or silver, to which was attached a small sponge. Inserted into the cavity of the palate, the sponge would, Paré explained, soak up the moisture 'distilling from the brain' and swell so that the metal piece would sit firmly in the mouth. Such a recourse was typical of Paré's inventiveness in prosthesis design, and it was apparently effective: the surgeon attested that 'I have observed [this method] not by once or twice, but by manifold trial. ${ }^{6}$ Paré, and later Johannes van Horne, also wrote of having seen men who had lost part of their tongue inserting a small piece of wood in their mouth to allow them to speak. ${ }^{7}$ In these cases, utility, sensory function, and sociability went hand in hand: Paré recorded that, having discovered this expedient, the man with the tongue-piece

4 Ibid., p. 227.

5 Sarah Covington, Wounds, Flesh, and Metaphor in Seventeenth-Century England (Basingstoke: Palgrave Macmillan, 2009), p. 85.

${ }^{6}$ Ambroise Paré, The Workes of That Famous Chirurgion Ambrose Parey Translated out of Latine and Compared with the French. by Th: Johnson (London: printed by Th. Cotes and R. Young, 1634), p. 873 .

7 Ibid.; Johannes van Horne, Micro-Techne; or, a Methodical Introduction to the Art of Chirurgery (London: printed by J. Darby, for T. Varnam and J. Osborne, and J. and B. Sprint, I7I7), pp. 6I-2. 
'always carried [it] hanging at his neck, as the onely interpreter of his mind, and the key of his speech'.

Of course, for many people with facial injuries, full restoration of function was impossible. Nobody could restore sight or hearing in people who had lost an eye or ear, and many mouth and palate injuries were to be imperfectly managed rather than fully cured. Nonetheless, it is clear that in such cases, Paré considered that the surgeon still had a job to do specifically, allowing the injured person to pass in able-bodied society as more or less aesthetically 'normal'. His recommendations for patients who had lost an eye exemplified this project. First he suggested the obvious expedient of an artificial eye, which might be 'counterfeited and enamelled, so that it may seem to have the brightnesse, or gemmie decencie of the naturall eye, into the place of the eye that is so lost'. ' If the patient was unable or unwilling to insert such an eye, however, Paré had another suggestion:

You must have a string or wiar, like unto womens eare-wiars, made to bind the head harder or looser as it pleaseth the patient, from the lower part of the head behinde above the eare, unto the greater corner of the eye, this rod or wiar must be covered with silke, and it must also be somewhat broade at both ends, lest that the sharpnesse thereof should pierce or pricke any part ... But the end wherewith the empty hollownesse must be covered, ought to bee broader than the other, and covered with a thin piece of leather, that thereon the colours of the eye that is lost may be shadowed or counterfeited. ${ }^{\text {IO }}$

Parés idea of a painted piece of leather attached with a system of thin wires around the head seems, at best, precarious. Nonetheless, it shows the lengths to which this surgeon was prepared to go to spare his patients the ignominy of wearing an eyepatch, as well as the possible discomfort and expense those patients were willing to endure in order to pass as ablebodied. The importance of having a 'normal' face recurred throughout Parés work. On people who had suffered facial cancers or burns, he commented that 'Such persons must be so trimmed and ordered, that they may come in a seemely manner into the company of others.' ${ }^{\text {'I }}$ Specifying the details of a good artificial nose, he advised that it should 'not want any thing that may adorne or beautifie the face'. ${ }^{12}$ As the father of military surgery, Parés advice was repeated in numerous surgical texts throughout the seventeenth and eighteenth centuries. In I7I7, for

\footnotetext{
${ }^{8}$ Paré, The Workes, p. 873. 9 Ibid., p. $869 . \quad{ }^{\text {Iо }}$ Ibid., p. $870 . \quad{ }^{\text {I }}$ Ibid., p. 874 .

${ }^{12}$ Ibid., p. 87 I.
} 
instance, van Horne's Micro-techne; or, a Methodical Introduction to the Art of Chirurgery followed Paré in observing that

we supply the want of an Eye with a Glass or golden one colour'd: and the loss of an Ear by thick Paper or Parchment painted; we repair the want of a Nose by Silver Plates: and though we are not so happy as to imitate the famous Taliacotius ... yet we can restore lost Teeth, if the speech be deficient, by factitious ones of Ivory; and we fix a Silver Lamina or Plate, when a Portion of the Palate is eaten away. ${ }^{\mathrm{I}}$

In this text he referred directly to Paré as an exemplar, as well as to the more contested Tagliacotian operation which I explore below. As in Paré's Workes, van Horne framed such interventions as 'Prosthesis, or a supplying by Art what is deficient', which 'conduces not a little to the Beauty of a human Body'. ${ }^{\mathrm{I}}{ }^{2}$

In all these examples, aesthetics and function are hardly separable. Restoring the damaged face is not a matter of vanity, or of enhancement. Rather, it is a restitution to basic social acceptability - the ability to be in company or to walk the streets without provoking horror. As Simon Dickie has explored, it was widely considered acceptable to mock and torment people with facial disfigurements during the seventeenth and eighteenth centuries, even among the so-called better sort. $^{\text {Is }}$ Furthermore, early modern medical practitioners and natural philosophers understood well the centrality of non-verbal expression to communication. John Bulwer's Chirologia (I648) dwelt on hand gestures, but included many facial expressions under that banner (for example, kissing the fingers). Chirologia's sister text, Philocophus, or, the Deaf and Dumb Man's Friend (1648) instructed its readers in lip reading among other skills. ${ }^{16}$ As Elizabeth Bearden has noted, Bulwer's texts promulgated an inclusive

I3 Horne, Micro-Techne; or, a Methodical Introduction to the Art of Chirurgery, pp. 6I-2.

I 4 Ibid., p. 6I.

is Simon Dickie, Cruelty and Laughter: Forgotten Comic Literature and the Unsentimental Eighteenth Century (Chicago: University of Chicago Press, 20 I I), p. I Io.

I6 John Bulwer, Chirologia, or, The Naturall Language of the Hand Composed of the Speaking Motions, and Discoursing Gestures Thereof: Whereunto Is Added Chironomia, or, The Art of Manuall Rhetoricke, Consisting of the Naturall Expressions, Digested by Art in the Hand, as the Chiefest Instrument of Eloquence, by Historicall Manifesto's Exemplified out of the Authentique Registers of Common Life and Civill Conversation: With Types, or Chyrograms, a Long-Wish'd for Illustration of This Argument (London: Tho[mas] Harper, sold by R. Whitaker, I644); John Bulwer, Philocophus, or, The Deafe and Dumbe Mans Friend Exhibiting the Philosophicall Verity of That Subtile Art, Which May Inable One with an Observant Eie, to Heare What Any Man Speaks by the Moving of His Lips: Upon the Same Ground... That a Man Borne Deafe and Dumbe, May Be Taught to Heare the Sound of Words with His Eie, of Thence Learne to Speake with His Tongue (London: printed for Humphrey Moseley, I 648). 
view of nature' in which one sense (sight) could stand in for another (hearing), thus de-stigmatizing sensory difference. ${ }^{17}$ Nonetheless, facial difference remained a special case: facial injury could impede one's own senses and offend the senses of those who looked upon it. In recognition of this fact, by I 687, Parliament had passed an act specifically against maiming, and injuries to the face were treated particularly seriously, such that in I722, two men were executed for having slit the nose of an acquaintance. ${ }^{18}$ As Alexander Read explained, 'without doubt a Maim in the Face must be the principal: for it disfigures the best favoured part'. ${ }^{19}$

\section{'Hypocrisy of Countenance'}

Supplying prostheses to fill in gaps on the face - lost palates, ears, eyes, and noses - was thus viewed as a matter of medical necessity, of the same order as bandaging a wounded arm or splinting a broken leg. As the century progressed, however, medical practitioners of various kinds started to offer kinds of prostheses which aimed not only to restore faces damaged by trauma and disease, but to improve a patient's overall appearance. Of these, probably the most ubiquitous were teeth. Dentures and tooth transplants had been available in one guise or another since ancient Egypt, but in the seventeenth century, the demand for - and consequently, innovation in - false teeth expanded as never before. In the words of Charles Allen, author of the pre-eminent English dentistry text of this period:

When our decay'd Teeth are so far gone before we think of any Remedy for their preservation, that whatever we can do, proves but fruitless ... or that some intolerable pain has made us to draw them: we are not yet to despair, and esteem ourselves toothless for all the rest of our life: the loss indeed is great, but not irreparable; there is still some help for it, the natural want may be supplied artificially, and herein Art imitates Nature so naifly [naturally], that when the succedaneous [permanent] Teeth ... are well set in, they cannot be distinguished from the natural ones. ${ }^{20}$

${ }^{17}$ Elizabeth B. Bearden, 'Before Normal, There Was Natural: John Bulwer, Disability, and Natural Signing in Early Modern England and Beyond', PMLA I 32:I (2017): 45.

I8 Anon, The Tryal and Condemnation of Arundel Coke Alias Cooke Esq; and of John Woodburne Labourer, for Felony, in Slitting the Nose of Edward Crispe (London: printed for John Darby and Daniel Midwinter, I722).

I9 Alexander Read, Chirurgorum Comes; or, The Whole Practice of Chirurgery (London: Edw. Jones, for Christopher Wilkinson, I687), p. 460.

${ }^{20}$ Charles Allen, Curious Observations on the Teeth (I687), ed. L. Lindsay (London: John Bale, Sons \& Danielsson, I924), p. I 2. 
Artificial and implanted teeth offered patients the chance to eat and speak normally, as well as to look younger and healthier. As a consequence, both kinds of dentistry became very popular. A. S. Hargreaves finds the incidence of tooth transplantation to have increased substantially from the later sixteenth century to the late eighteenth century, at which point ceramic alternatives became commonplace. ${ }^{2 I}$ Donor teeth might come from corpses, or from those still living, who found that strong, white teeth proved a saleable commodity in times of need. Moreover, Mark Blackwell contends that in the eighteenth century, dentistry was 'riven by commercialism and fashion'. ${ }^{22}$ New teeth were less a medical procedure than a luxury commodity.

In eighteenth-century newspapers, the advantages of the new dentistry were eagerly described. In 1707, for instance, John Watts promised that

[he] sets in Artificial Teeth so firm as to eat with them, and so exact as not to be discover'd from Natural: They are an Ornament to the mouth, and a very great help to Speech, and not to be taken out every Night, as is by some falsely suggested, but may be worn Years together. ${ }^{23}$

The theme of undetectability was common among such advertisements, with other proprietors claiming to set in teeth 'so even, neat, and firm, that they need not be removed for seven Years, and [patients] may eat with them as well as with their former, and cannot be distinguish'd from their natural ones'. ${ }^{24}$ Like the commodification of the castrato body discussed in Chapter I, the commodification of teeth was indexed to the rise of newspapers and periodicals. As with castrati, however, the alliance between bodily alteration and commercial interest provoked unease in many observers. In her article on wigs in the eighteenth century, Lynn Festa notes that the 'shuttl[ing] between different individuals' of such objects 'erodes the boundaries that set the individual subject off from the world', creating both disputes over the ethics of harvesting hair from the heads of the poor and concerns over personal integrity:

the liberal idea of the subject as an individual jostles against the notion of the self as the possessor of detachable parts. If the individual is

\footnotetext{
${ }^{21}$ A. S. Hargreaves, White as Whales Bone: Dental Services in Early Modern England (Leeds: Northern Universities Press, I998).

22 Mark Blackwell, "'Extraneous Bodies”: the Contagion of Live-Tooth Transplantation in LateEighteenth-Century England', Eighteenth-Century Life 28: I (2004): 2 I-68.

23 Flying Post or The Post Master, 7-Io June 1707.

24 Weekly Journal or British Gazetteer, I6 March I7I7. See also Daily Courant, I I December I7I9.
} 
composed of removable and detachable layers that it owns, what exactly is doing the owning? ${ }^{25}$

As a rarer commodity (and one irreplaceable for the donor), dentures and implants made from real teeth heightened these concerns, and medical practitioners, moralists, and satirists alike questioned the ethics of putting teeth from one human being into another. Allen, for instance, stated that

I do not like that method of drawing Teeth out of some folks heads, to put them into others, both for its being too inhumane, and attended with too many difficulties; and then neither could this be called the restauration of Teeth, since the reparation of one, is the ruine of another; it is only robbing Peter to pay Paul. ${ }^{26}$

Allen's objection was based explicitly on the ethics of removing teeth from human beings for transplantation, since elsewhere he suggested that one might usefully implant teeth from dogs, sheep, or baboons into humans: 'In such case I do not only approve of it as lawful and facile, but so also esteem it as very profitable and advantageous. ${ }^{27}$ Baboons aside, however, human tooth transplantation almost inevitably involved the exploitation of the young and poor by the old and rich. John Ward, for instance, recorded in his diary hearing of 'a Lady [who] having a rotten tooth drawn caused a sound tooth at the same time to bee drawn from her waiting maid, which was substituted and in time so rooted that shee could make use of itt as well as of any other ${ }^{2}{ }^{28}$ Such tales were unsurprisingly distasteful to many observers. Blackwell notes, 'This age disparity was exploited to good effect by writers and artists who imply that the beauty of the old can be maintained only by disfiguring the young ... on an unmannerly species of consumption that involves the nation's harvesting its young stock, cannibalizing its own progeny. ${ }^{, 29}$

Notably, neither Allen nor Ward seems to have viewed tooth implantation - either from humans or from animals - as a possible source of contagion. This is in contrast to discourses about grafted noses (below) and transplanted limbs (Chapter 4) in which differences of race and class figured prominently, with 'foreign' additions perceived as threatening the integrity of the 'original' body. This may have been because implanted

${ }^{25}$ Lynn M. Festa, 'Personal Effects: Wigs and Possessive Individualism in the Long Eighteenth Century', Eighteenth-Century Life 29:2 (2005): 48.

26 Allen, Curious Observations on the Teeth, p. I3. ${ }^{27}$ Ibid.

${ }^{28}$ John Ward, 'Notebook of John Ward, Vol. I' (c. I650-70), Folger Shakespeare Library, v.a. 284299, p. 2 II.

29 Blackwell, 'Extraneous Bodies', 38. 
teeth were usually viewed as senseless. Thus in Pierre Fauchard's I746 Treatise on the Teeth, he observed that 'I could not imagine that a tooth transferred from one mouth to another could be susceptible of pain, in view of the fact that its nerve and the membranes had been cut off.' ${ }^{30}$ Instead, objections to false and implanted teeth usually approached the subject from the angle of social morality. As Farah Karim-Cooper has identified, and as I discuss below, the lines between prostheses and cosmetics were often blurred. Both entailed the 'systematic assemblage of material goods' to supplement elements of the body that were lacking. ${ }^{3 \mathrm{I}}$ Given that some prostheses such as false eyes were clearly non-functional in sensory terms, the perceived difference between bodily additions that were cosmetic and those that were deemed medically necessary depended on numerous factors, including the nature of the supplier, the circumstances of the original 'lack', and the intentions of the user-wearer.

This tension between bodily additions as acts of vanity or acceptable restorations was recognised in I656, when John Gauden framed a fictional discourse between 'Two Ladies' arguing over the morality of cosmetics. Against cosmetics, one lady argues:

while we disguise and alter our face ... we are not what we seem to be to our selves... Whereas the wise Creator hath by nature impressed on every face of man and woman, such Characters, either of beauty, or Majesty, or at least of distinction, as he sees sufficient for his own honor, our content, and others sociall discerning or difference, whereby to avoyd confusions or mistakes. ${ }^{32}$

However, Gauden's second lady, arguing in favour of cosmetics, points out the hypocrisy inherent in sharp distinctions between redressing bodily faults and augmenting beauty:

Who ever is so impertinent a bigot, as to find fault, when the hills and dales of crooked and unequall bodies, are made to meet without a miracle, by some iron bodies, or some benign bolsterings? Who fears to set straight or hide the unhandsom warpings of bow legs and baker feet? What is there as to any defect in nature, whereof ingenuous art, as a diligent handmaid waiting on its mistresse, doth not study some supply or other? So farre as to

${ }^{\circ}$ Pierre Fauchard, The Surgeon Dentist, or, Treatise on the Teeth, trans. Lillian Lindsay, 2nd edition (Pound Ridge, NY: Milford House, I 969), p. I43. Fauchard noted one case in which the new tooth had gained sensation, but this was the exception, not the rule.

3I Farah Karim-Cooper, Cosmetics in Shakespearean and Renaissance Drama (Edinburgh: Edinburgh University Press, 2006), p. I I 4 .

32 John Gauden, A Discourse of Auxiliary Beauty. Or Artificiall Hansomnesse. In Point of Conscience between Two Ladies (London: printed for R. Royston, I656), p. 34. 
graff in silver plates to crackt sculls, to furnish cropt faces with artificiall noses, to fill up the broken ranks and routed files of the teeth with ivory adjutants or lieutenants. ${ }^{33}$

Overall, Gauden suggested that cosmetics were not qualitatively different from prosthetics. The use of cosmetics was therefore not morally reprehensible, provided that they were employed sparingly, and not used to entice or entrap men. It is clear, however, that many early modern people drew different conclusions about the continuity of prostheses and cosmetics. Positioned at the boundary between medicine and beautification, false and implanted teeth became vulnerable to the sort of misgivings which Gauden's first disputant identified about cosmetics: that they disguised the face, and impeded the discernment of rich from poor, young from old. The judgements casually levelled against users of false teeth could be vitriolic. Samuel Pepys, for example, recorded in his diary that

Sir William Batten doth rail still against Mr Turner and his wife (telling me he is a false fellow, and his wife a false woman and hath rotten teeth and false, set in with wire) and as I know they are so, I am glad he finds it so. ${ }^{34}$

For Pepys, Mrs Turner's rotten teeth were a physical expression of her rotten character, and should be visible to others on that basis. She and her husband were, as Pepys stresses, 'false' both in body and in behaviour. Similarly, Robert Herrick's Hesperides, published in 1648, included an epigram on 'Glasco':

Glasco had none, but now some teeth has got,

Which though they furre, will neither ake, or rot.

Six teeth he has, whereof twice two are known

Made of a Haft, that was a mutton-bone.

Which not for use, but meerly for the sight,

He wears all day, and drawes those teeth at night. ${ }^{35}$

For both authors, false teeth seemed an unfair advantage in the social game. Their subjects had not the face they deserved, but the one they had bought. The fact that Glasco's teeth are made from a haft, or knife handle, aptly represents the technologisation of the body offered by such procedures, in which the natural and artificial meet. 'Haft' may also underline the duplicity Herrick sees as inherent in this set-up: the

33 Ibid., pp. 59-60.

34 'Monday Io October I664', The Diary of Samuel Pepys, accessed 6 April 2018, www.pepysdiary .com/diary/I 664/Io/Io.

35 Robert Herrick, 'Upon Glasco. Epig.' in Robert Herrick, ed. Stephen Romer (London: Faber and Faber, 2010), n.p. 
word was also employed as a verb meaning 'to use subtlety or deceit, to use shifts or dodges' ${ }^{36}$

False teeth - in particular, implanted teeth - raised questions about the interface between one body and another, between bodies and technology, and between bodies and the people who 'read' them. We might thus consider false teeth as prostheses within the 'free-ranging' definition of that word advanced by Will Fisher in his 2006 Materializing Gender. ${ }^{37}$ Discussing items such as beards, codpieces, and handkerchiefs, Fisher argues that such accoutrements functioned as 'supplementary' to the early modern body in a Derridean sense, that is, both an addition to one's 'natural' self and a necessary part of it. ${ }^{38}$ Fisher's particular interest is in those items that acted dually as contributors to and markers of the assignment of gender, which he argues was based on a number of differently 'weighted' signs. While genitalia were the most heavily weighted indicators of masculine or feminine identity, clothing, voice, and manners all had a role to play. Facial prostheses in general, and false teeth in particular, seem likewise to have functioned as 'weighted' signs - this time, of (dis)ability and socio-economic status. Whilst they may not have been part of the 'natural' material body, they were intrinsic to the lived experience of the embodied subject, altering both their social and sensory worlds.

The early modern period possessed dynamic paradigms for thinking about these problems of appearance and identity, particularly in relation to social class. As Alexandra Shepard has shown, it was held in the sixteenth and seventeenth centuries that virtues such as chivalry, honesty, and bravery could be found 'in' the nobility in a physiological sense. Indeed, 'aspirations to the temperate [bodily] ideal were restricted to an elite minority variously distinguished by their moral, religious, and, more implicitly, their social superiority'. ${ }^{39}$ This was not a quaint tradition, but a live and important issue. As we have seen in the case of castrati, the fastchanging economic climate of the early modern period had the potential both to undermine and to render sacrosanct the perceived connection between bodily qualities and social standing. Mark Breitenberg has

36 ' $†$ Haft, v.2', in OED Online (Oxford University Press), accessed I February 201 8, www.oed.com/ view/Entry/83190.

37 Will Fisher, Materializing Gender in Early Modern English Literature and Culture (Cambridge: Cambridge University Press, 2006), p. 29.

${ }^{38}$ Ibid., p. 27.

39 Alexandra Shepard, Meanings of Manhood in Early Modern England (Oxford: Oxford University Press, 2006), p. 49. 
observed how "the term "aristocratic body" denotes not a readily distinguishable rank in early modern England ... but rather an ideal to which various degrees of the gentry might aspire, or a symbol that might legitimate newly acquired status as if it were inherent'. ${ }^{40}$ Accordingly, the body might function to bridge the gap between economic status, which was changeable, and 'rank', which was generally inherited. Equally, it might prevent the nouveau riche (that is, those who attained wealth through commerce rather than by birth) from truly assimilating into aristocratic society. Thus attributes such as height potentially functioned, in Fisher's terms, as 'weighted signs' of socio-economic status. As so often in such discourses, the body imagined as noble or otherwise was paradigmatically male, partly because the male seed was commonly understood as that which shaped the gross matter supplied by females in the generative process. ${ }^{4 \mathrm{I}}$

While seductive, however, notions of the naturalness of noble bodies were not uncomplicated. Many physical assessments of nobility were more or less founded on physiognomy, the notion that character could be read in a person's facial features. Physiognomy had a long history, reaching back to Greek classicism, and bolstered by the Galenic notion that bodily temperature might govern characterological temperament. ${ }^{42}$ Mixing pseudo-science and scurrility, it proved immensely popular for much of the early modern period: Martin Porter estimates that there were around 300,000 copies of texts on physiognomy circulating in England during the period I 470-1780. ${ }^{43}$ Nonetheless, physiognomy seemed to lose much of its authority in the early eighteenth century, shifting from a fairly respectable branch of natural philosophy to a 'vulgarised' parlour game (though later to be revived by Johann Caspar Lavater's 1775 Essays on Physiognomy). Among the chief factors in this decline was a rise in the use of cosmetics, which, just as Gauden's Discourse of Auxiliary Beauty had predicted, went hand-in-hand with an increasing emphasis on fashion and personal selffashioning. ${ }^{44}$ As Roy Porter points out, this necessarily undermined the

$4^{\circ}$ Mark Breitenberg, Anxious Masculinity in Early Modern England (Cambridge: Cambridge University Press, I996), p. 73.

${ }^{4} \mathrm{I}$ See Matthew Cobb, Generation: the Seventeenth-Century Scientists Who Unraveled the Secrets of Sex, Life, and Growth (New York: Bloomsbury Publishing USA, 2008), pp. 2 10-20.

42 Roy Porter, Flesh in the Age of Reason (London: Allen Lane, 2003), pp. 245-46; Bernadette Wegenstein, The Cosmetic Gaze: Body Modification and the Construction of Beauty (Cambridge: MIT Press, 20I2), pp. 5-8.

43 Martin Porter, Windows of the Soul: Physiognomy in European Culture, 1470-I780 (Oxford: Clarendon Press, 2005), p. 96.

44 Porter, Flesh in the Age of Reason, pp. 244-57. 
'universal sign-grammar of good and bad'45 promised by physiognomic reading:

It had always been acknowledged, of course, that reading character might present difficulties, rather like peering through a glass darkly; but what if looks were actually designed to lie? How could physiognomy cope with systematic hypocrisy of countenance? ${ }^{46}$

However it was generated, 'hypocrisy of countenance' undermined the trust on which relationships were based and threatened the very assumptions upon which social order was based. Nowhere was this hypocrisy demonstrated more clearly, and more outrageously, than in early modern nose grafting.

\section{Reputation and Rhinoplasty}

In 1704, gentlewoman Sarah Cowper recorded in her diary her encounter with an acquaintance whose nose had collapsed as a result of venereal disease. Cowper did not seem particularly perturbed that the woman had contracted the disease, nor that it had damaged her face to such an extent. She was, however, a little surprised by the woman's response to this misfortune:

The Lady Millbank whose husband (tis said) gave her the disease of St Job, to that degree as her nose fell flatt, yet was afterwards so well cured that she bore Sr [Millbank] eight children that are handsome, sound, and well. This Lady was in Health but five days since and now is dead of the small pox. I was commending her for she seemed well assured, content, and easie with so unfortunate a disaster. A La[dy] made answer that moreover she was airy, brisk, and a great Dancer. Methought that was more than enough, for by no means shou'd any Woman dance without a nose, tho' never so innocently lost. ${ }^{47}$

Cowper's cutting understatement was rather typical of her diaries, in which most of her acquaintances, as well as her family and servants, are judged and found wanting. Lady Millbank's fate, however, also tells us something of the importance of the nose in early modern culture, and the ignominy which accompanied losing it. Within the physiognomic tradition described above, the nose was a particularly important feature, the size and shape of which was believed to denote personal qualities including

45 Ibid., p. $249 . \quad{ }^{6}$ Ibid., p. 25 I.

47 Sarah Cowper, 'Diary, Volume I, I700-I702' (Defining Gender, I450-I9I0, n.d.), p. 219, www gender.amdigital.co.uk (emphasis added). 
'straitnesse of heart and indignation of thought'. ${ }^{48}$ In privileging this organ, physiognomists shared something with more informal, but longstanding adages about the significance of the nose. In the popular imagination, the size of a man's nose might correspond with that of his penis, while, as Peter Berek has shown, comedically oversized noses were often used to denote Jewishness on the early modern stage. ${ }^{49}$ The mutilated, slit, or amputated nose, meanwhile, was 'situated within the idiom of insult', marking out the bearer as deceitful, roguish, or seditious, and being closely associated with castration. ${ }^{50}$ This logic underlay both extrajudicial and judicial maiming, both aimed at 'exacerbating the risk of dishonour'. ${ }^{5 \mathrm{I}}$ As Cowper's account demonstrates, the collapsed or missing nose was most strongly associated with venereal disease, such that - especially for women - this feature was instantly readable to any onlooker. In her extensive work on rhinoplasty, Emily Cock describes how the physiognomic tradition of viewing long noses as sexual intersected with readings of the missing nose as indicating pox, such that 'texts focussed on bawds and whores repeatedly feature women who have lost long noses, or authorial surprise that they should still have one'. ${ }^{52}$ In this hostile environment, it is unsurprising that those with missing or collapsed noses sought to remedy the lack. Attempts to palliate the physical and social effects of a lost nose usually consisted of artificial noses made of metal, paper, or leather. These devices were often painted or enamelled to resemble the original as closely as possible, though the effect was probably unconvincing at close quarters. ${ }^{53}$ Moreover, prosthetic noses brought their own problems. Holly Dugan points out that prosthetic noses hindered rather than helped one's ability to smell, and functioned as a 'visible reminder' of the dangers of pox. ${ }^{54}$ In the absence of a better solution, prosthetic noses at least covered

${ }^{8}$ Thomas Vicary, The Surgion's Directorie, for Young Practitioners, in Anatomie, Wounds, and Cures, $\checkmark c$. Shewing, the Excellencie of Divers Secrets Belonging to That Noble Art and Mysterie. Very Usefull in These Times upon Any Sodaine Accidents. And May Well Serve, as a Noble Exercise for Gentlewomen and Others; Who Desire Science in Medicine and Surgery, for a Generall Good (London: printed by T. Fawcett, I65I), p. 37.

49 Garthine Walker, Crime, Gender and Social Order in Early Modern England (Cambridge: Cambridge University Press, 2003), p. 92; Peter Berek, "Looking Jewish" on the Early Modern Stage', in Religion and Drama in Early Modern England: the Performance of Religion on the Renaissance Stage, ed. Jane Hwang Degenhardt and Elizabeth Williamson (Farnham: Ashgate, 20II), pp. 55-70.

so Walker, Crime, Gender and Social Order in Early Modern England, p. 92; Patricia Skinner, 'The Gendered Nose and Its Lack: "Medieval" Nose-Cutting and Its Modern Manifestations', Journal of Women's History 26:I (2014): 45-67; Cock, Rhinoplasty and the Nose, p. 3 I.

${ }_{51}$ Cock, Rhinoplasty and the Nose, p. $32 . \quad 52$ Ibid., p. $27 . \quad 53$ Ibid., pp. 38-42.

${ }_{54}$ Holly Dugan, The Ephemeral History of Perfume: Scent and Sense in Early Modern England (Baltimore: Johns Hopkins University Press, 201 I ), p. 96. 
the facial bones exposed by tissue loss, which allowed one to venture outdoors without causing horror. For a few individuals, however, the effect of losing their nose was such that they were prepared to undergo a dangerous and pioneering form of reconstruction.

In one form or another, reconstructive rhinoplasty has been a fixture of the medical profession for more than two thousand years. Jerome Webster and Martha Teach Gnudi find nose reconstruction operations to have been first detailed in the ancient Hindu surgical writings of Susrata. ${ }^{55}$ Though its history thereafter is murky, at some point, probably by the tenth century $\mathrm{AD}$, this text's secrets travelled westward to the Mediterranean. ${ }^{56}$ The first detailed account of the nose-reconstruction operation being practised in Europe comes from the fifteenth-century Italian historian Bartholommeo Fazio, describing the work of father-andson surgeons Branca the Elder and Antonio Branca. ${ }^{57}$ In the sixteenth century, a Bolognese surgeon, Gaspare Tagliacozzi, is believed to have learned his craft from the Brancas. He became synonymous with the nasal graft, with which he could apparently craft a nose 'so resembling nature's pattern, so perfect in every respect that it was [the patients'] considered opinion that they like these better than the original ones which they had received from nature'. ${ }^{58}$

Tagliacozzi's seminal text on nasal grafting, De Curtorum Chirurgia per Institionem, was first published in Venice in I 596-7. It contained painstakingly detailed instructions for this operation which suggested that the author had undertaken the procedure many times, despite the fact that it appears to have been a long, risky, and painful process. To craft the new nose, a portion of the skin of the upper arm first had to be lifted up with forceps and cut on two sides, before lint was placed underneath to prevent the skin reuniting with the flesh. ${ }^{59}$ When the swelling from this wound had died down, one was to cut the third edge of the skin flap, fold it backwards, and bandage it. ${ }^{60}$ After two weeks or so, one could consider suturing the flap - still attached at one end to the arm - to the mutilated

55 Martha Teach Gnudi and Jerome Pierce Webster, The Life and Times of Gaspare Tagliacozzi, Surgeon of Bologna, I545-I599. With a Documented Study of the Scientific and Cultural Life of Bologna in the Sixteenth Century (New York: H. Reichner, 1950), p. Io6.

56 Ibid., pp. I07-8. $\quad 57$ Ibid., p. I Iо.

58 Gaspare Tagliacozzi, 'Letter to Hieronymus Mercurialis', in Gnudi and Webster, The Life and Times of Gaspare Tagliacozzi, pp. I 36-9. For a detailed examination of the circulation of rhinoplasty texts in early modern Europe, see Cock, Rhinoplasty and the Nose, pp. I I 2-49.

59 Gaspare Tagliacozzi, De Curtorum Chirurgia per Institionem, ed. Robert M. Goldwyn, trans. Joan H. Thomas (New York: Gryphon Edition, 1996), pp. I33-5.

60 Ibid., pp. I 50-7. 
nose, binding the area with specially made bandages. ${ }^{61}$ For the first week, it was essential that the patient avoid any movement, even talking, if the skin was to have a chance of adhering. Three weeks later, one might fully detach the skin from the arm and continue shaping the nose. However, it would be a further six to nine weeks before the surgeon could form the nose's columella, and two more weeks before the nostrils could be formed. ${ }^{62}$ Tagliacozzi himself pointed out difficulties which attended every step of the operation. For instance, patients were required to have their heads shaved prior to the procedure - not because of infection risk, but because the movement of scratching one's lice-ridden head would ruin the shape of the finished nose. ${ }^{63}$ The new nose needed to be made considerably larger than eventually required, since the skin could be expected to contract over the first year of adhesion. Moreover, it was an inescapable fact that hair might grow on the new nose 'so luxuriant that it must be shaved'. ${ }^{64}$ The result was certainly better than the 'horrendous and abominable sight' of a missing nose, with the internal bones and flesh of the face exposed. ${ }^{65}$ Still, Tagliacozzi admitted, 'The grafted nose differs from the normal nose in its color, softness, sensitivity, size, and hirstuteness, as well as in the magnitude of the nostrils. ${ }^{66}$

Partly because of the difficulties Tagliacozzi described, and partly because of misinterpretations and corruptions of his instructions, it has been widely believed that his operation fell out of favour in the later sixteenth century, leaving plastic surgery to stagnate until the First World War revived the craft. ${ }^{67}$ However, Cock has shown that copies of De Curtorum Chirurgia were circulated among British surgeons of the seventeenth and eighteenth centuries. ${ }^{68}$ Moreover Alexander Read, who had long taken an interest in Parés techniques for facial reconstruction, became strongly associated with the promulgation of Tagliacozzi's work. Cock notes that 'A translation of book two of Tagliacozzi De curtorum chirurgia outlining the rhinoplasty procedure was attached to a posthumous selection of Read's works', titled Chirurgorum comes and possibly edited by James II's physician Francis Bernard. ${ }^{69}$ It is unclear if Read or his

\footnotetext{
${ }_{61}$ Ibid., pp. I70-7. ${ }_{66}^{62}$ Ibid., pp. 200-2. ${ }_{63}^{63}$ Ibid., pp. I 2-I3. ${ }^{64}$ Ibid., p. I Io.

${ }^{67}$ On the revival of Tagliacotian rhinoplasty from I 800 onward, see Cock, Rhinoplasty and the Nose, pp. 9I-IO5.

68 See Emily Cock, “'Lead[ing] 'em by the Nose into Publick Shame and Derision”: Gaspare Tagliacozzi, Alexander Read and the Lost History of Plastic Surgery, I600-I80o', Social History of Medicine 28:I (2015): I-2I, https://doi.org/I0.1093/shm/hku070; Cock, Rhinoplasty and the Nose, pp. I I 2-49.

69 Cock, Rhinoplasty and the Nose, p. I 12.
} 
contemporaries actually carried out the operation described in this text. What is clear, however, is that public and medical interest in the nose reconstruction operation continued unabated throughout the seventeenth century. ${ }^{70}$ Moreover, in the latter half of the seventeenth century, this interest became increasingly coloured by the idea that the operator might take the skin or flesh of another person to supply the graft material for nose reconstruction. This idea had no basis in Tagliacozzi's Curtorum. Indeed, he explicitly dismissed the possibility of inter-personal grafts on the grounds that 'the danger to the patient would be considerable and the outcome dubious, if not hopeless'. ${ }^{71}$ Nevertheless, later writers showed themselves either unaware of Tagliacozzi's statement or simply disinclined to let the truth get in the way of a good story. Jean-Baptiste van Helmont, for instance, attested that

A certain inhabitant of Bruxels, in a combat had his nose mowed off, addressed himself to Tagliacozzus a famous Chirurgeon ... that he might procure a new one; and when he feared the incision of his own arm, he hired a Porter to admit it, out of whose arm, having first given the reward agreed upon, at length he dig'd a new nose. About thirteen months after his return to his own Countrey, on a sudden the ingrafted nose grew cold, putrified, and within a few days, dropt off. To those of his friends, that were curious in the exploration of the cause of this unexpected misfortune, it was discovered, that the Porter expired, neer about the same punctilio of time, wherein the nose grew frigid and cadaverous. ${ }^{72}$

This account, like others, touched on the doctrine of sympathy which I discuss below. The grafted flesh, they suggested, would die at the same time as its original owner, and thus had to be sourced wisely. In I662, James Cooke's Mellificum Chirurgiae provided readers with a brief description of the operation, adding that the grafted tissue 'may be either from their own bodies or some others: if they choose anothers [sic], let them be sure they are longer lived than themselves, lest they lose their Nose again before they die'. ${ }^{73}$ M. de la Vauguion likewise asserted that 'the Ancients

70 Cock, "'Lead[ing] 'em by the Nose"', 8-I 2; Gnudi and Webster, The Life and Times of Gaspare Tagliacozzi, pp. 273-80, 303-7.

${ }^{71}$ Tagliacozzi, De Curtorum Chirurgia per Institionem, pp. 76-7.

72 Johan [Jean] Baptiste van Helmont, A Ternary of Paradoxes. The Magnetick Cure of Wounds, trans. Walter Charleston, 2nd edition (London, I650), pp. I3-I4.

${ }^{73}$ James Cooke, Mellificium Chirurgie, or the Marrow of Many Good Authors Enlarged: Wherein Is Briefly, Fully, and Faithfully Handled the Art of Chirurgery in Its Four Parts, with All the Several Diseases unto Them Belonging: Their Definitions, Causes, Signes, Prognosticks, and Cures, Both General and Particular (London: printed by T.R. for John Sherley, I662), p. 374. 
repaired the loss of parts, as a Nose cut off or the like, by inoculating Flesh out of the Arms or Buttocks of their Slaves'. ${ }^{74}$

That these stories began to circulate widely from the middle of the seventeenth century was no coincidence. In the I660s, members of the Royal Society were testing the limits of biological experimentation. Primarily using dogs, they made blood transfusions and skin grafts, first between different parts of the same animal, and then between one animal and another. ${ }^{75}$ Moreover, some experiments tested the boundaries between one species and another. ${ }^{76}$ In 1667-8, blood transfusions between animals and humans were undertaken in France and England, and were eagerly documented in the Royal Society's Philosophical Transactions. The procedure's pioneer, Jean-Baptiste Denis, claimed to have cured several patients of madness by infusing them with lamb's or calf s blood, and in I667, Edmund King and some colleagues transfused blood from a sheep to a clergyman. ${ }^{77}$ The aim of these transfusion experiments was not to prevent death through blood loss, but to ascertain the role of blood in determining bodily processes and behaviours. Writing on dog-to-dog transfusions in $\mathrm{r} 666$, for instance, Robert Boyle pondered

Whether by this way of Transfusing Blood, the disposition of individual Animals of the same kind, may not be much altered (As whether a fierce Dog, by being often quite new stocked with the blood of a cowardly Dog, may not become more tame; \& vice versa, \&c.? $7^{78}$

Tellingly, Boyle also wondered whether dogs which received transfusions would retain their characters and abilities. Would they, for example, 'fawn

74 M. de la Vauguion, A Compleat Body of Chirurgical Operations, Containing the Whole Practice of Surgery. With Observations and Remarks on Each Case. Amongst Which Are Inserted, the Several Ways of Delivering Women in Natural and Unnatural Labours. The Whole Illustrated with Copper Plates, Explaining the Several Bandages, Sutures, and Divers Useful Instruments. (London: printed for Henry Bonwick, T. Goodwin, M. Wotton, B. Took, and S. Manship, I699), p. 355.

75 David Hamilton, A History of Organ Transplantation: Ancient Legends to Modern Practice (Pittsburgh: University of Pittsburgh Press, 2012), pp. 25-6; Anita Guerrini, 'The Ethics of Animal Experimentation in Seventeenth-Century England', Journal of the History of Ideas 50:3 (1989): 39I-407.

${ }^{76}$ Paolo Savoia's Gaspare Tagliacozzi and Early Modern Surgery, published as this book was going to press, also explores the connection between Tagliacozzi's work and horticultural grafting. See Gaspare Tagliacozzi and Early Modern Surgery: Faces, Men and Pain (London: Routledge, 2019), pp. I $40-82$.

77 Holly Tucker, Blood Work: a Tale of Medicine and Murder in the Scientific Revolution (New York: W. W. Norton, 20I2), pp. 163-70; Guerrini, 'The Ethics of Animal Experimentation in Seventeenth-Century England', 40 I.

${ }^{78}$ Robert Boyle, 'Tryals Proposed by Mr Boyle to Dr Lower, to Be Made by Him, for the Improvement of Transfusing Blood out of One Live Animal into Another', Philosophical Transactions, I I February i666. Folger Shakespeare Library. 
upon' their owners? Would retrieving dogs continue to retrieve and bloodhounds to follow scents? ${ }^{79}$

Though discussants of Tagliacozzi did not explicitly link his nose grafts to these blood transfusions, it was not a great leap to see that both procedures raised questions about the relations between the 'stuff' of the body, the subjective experience of the body, and selfhood as a whole. These queries were likewise provoked by the doctrine of sympathy, which acquired a scientific gloss in the later seventeenth century. Influenced by Paracelsus and Van Helmont, adherents to this doctrine contended that all physical bodies shared a connection with one another, either mystically or (in later iterations of the doctrine) via material qualities. ${ }^{80}$ Whilst some dismissed the theory as quackery, work by Seth Lobis has convincingly demonstrated that sympathy remained a topic of discussion throughout the seventeenth and into the eighteenth century, being reworked into new forms rather than wholly rejected. ${ }^{8 \mathrm{I}}$ Among the most influential writers on sympathy were Sir Kenelm Digby and Robert Fludd, both of whom defended the idea of curing by sympathy, with 'sympatheticall powder' and 'weapon-salve' respectively. ${ }^{82}$ Using sympathetic connection between a weapon and the wound it had created, or between a drop of blood and the whole body, the authors asserted that even serious injuries might be cured without so much as seeing the patient. ${ }^{83}$ Sympathy was the supposed force behind the Anodyne Necklace, a device discussed earlier in this book. Moreover, unlike the Royal Society's experiments, the doctrine of sympathy was explicitly connected to the Tagliacotian operation, and even took anecdotes about that operation as proof of theory. Fludd, for instance, told the story of an Italian nobleman who had, after losing his

79 Ibid.

${ }^{80}$ Seth Lobis, The Virtue of Sympathy: Magic, Philosophy, and Literature in Seventeenth-Century England, Yale Studies in English (New Haven: Yale University Press, 201 5), pp. 9-1 3.

8I Cock, Rhinoplasty and the Nose, pp. I 58-69.

82 Kenelm Digby, A Late Discourse, Made in a Solmne Assembly of Nobles and Learned Men at Montepellier in France: By Sr Kenelme Digby, Knight, of c. Touching the Cure of Wounds by the Powder of Sympathy; With Instructions How to Make the Said Powders; Whereby Many Other Secrets of Nature Are Unfolded, trans. R. White (London: printed for R. Lownes and T. Davies, I658); Robert Fludd, Doctor Fludds Answer Vnto M. Foster or, The Squeesing of Parson Fosters Sponge, Ordained by Him for the Wiping Away of the Weapon-Salve Wherein the Sponge-Bearers Immodest Carriage and Behauiour towards His Bretheren Is Detected; the Bitter Flames of His Slanderous Reports, Are by the Sharpe Vineger of Truth Corrected and Quite Extinguished: And Lastly, the Verrtuous Validity of His Sponge, in Wiping Away of the Weapon-Salve, Is Crushed out and Cleane Abolished (London: printed for Nathaneal Butter, I63I).

83 Lobis, The Virtue of Sympathy, pp. 45-50. 
nose, persuaded his slave to provide the flesh needed to make another. Afterwards, he reported,

The slave being healed and rewarded, was manumitted, or set at liberty, and away he went to Naples. It happened, that the slave fell sicke and dyed, at which instant, the Lords nose did gangrenate and rot; whereupon, the part of the nose which hee had of the dead man, was by the Doctors advice cut away. ${ }^{84}$

Fludd insisted that this phenomenon should be attributed not to the 'trumpery of the divell' but rather to 'God's vivifying spirit', which operated so remarkably that despite the distance between the nose's original owner and its new possessor, 'neither the tall Hills of Hetruria; nor yet the tall Appenine mountaines could stop the concourse and motion of these two spirits, or rather one spirit continuated in two bodies'. ${ }^{85}$ Less hyperbolically, Digby posited that 'artificiall noses that are made of the flesh of other men ... do putrifie as soon as those persons out of whose substance they were taken come to die, as if that small parcell of flesh ingrafted upon the face did live by the spirits it drew from its first root, and source'. ${ }^{86}$ While some discussions of sympathetic cure were decidedly mystical in emphasis, Digby in particular viewed this phenomenon as a mechanistic one, in which atoms were attracted like to like. ${ }^{87}$

What was the effect of all this scientific speculation on men and women with collapsed or missing noses? It seems clear that the scientific interest in sympathy and Tagliacozzi did not cause surgeons to actually start engrafting new noses. As had long been the case, people who lost their noses had to rely on false ones of various kinds. Nonetheless, medical and scientific speculation on the possibility of allografting (that is, grafting from one individual to another) had an impact on the ways in which bodily integrity and partition could be imagined. My own 2018 article on homoplastics, sympathy, and the noble body in the Tatler examines in detail a piece by

\footnotetext{
84 Fludd, Doctors Fludds Answer, p. I32. $\quad{ }^{85}$ Ibid., p. I33.

86 Digby, $A$ Late Discourse, pp. I I 5-I6.

87 The exact workings of sympathetic cure remained confused, but Lobis explains that in the case of a man cured by applying sympathetic powder to his bloodied garter: 'The blood atoms on the garter are attracted to those of the wound, where they are more plentiful. When the powder is added to the garter, light, which enables the cure, carries both the blood atoms and those of the vitriol in the powder and diffuses them in the air, where they are borne directly to the wound ... The aeration of the vitriol concentrates [its] virtue, and so the powder is more effective when applied at a distance than when it is administered directly' (Lobis, The Virtue of Sympathy, pp. 49-50).
} 
Joseph Addison, in which he satirises the Tagliacotian operation. ${ }^{88}$ Imagining a slew of petty nobility receiving new noses, he goes on to envisage the disruptive possibilities of sympathy between noble noses and ignoble buttocks. Addison's piece takes its departure from Samuel Butler's Hudibras (I674-8):

So learned Talicotius from

The brawny part of Porter's bum

Cut supplemental noses, which

Lasted as long as parent breech:

But when the date of nock was out,

Off drop'd the sympathetic snout. ${ }^{89}$

It shows how allografting might undermine the association between noble characters and noble bodies, between one's face and one's deeds. Moreover, Addison draws from a contemporary culture seemingly obsessed with uncovering the disjuncture between appearances and reality, from Jonathan Swift's vision of Celia at her toilet to Edward Ward's gleeful description of 'Ugly' and 'No-Nose' Clubs. ${ }^{90}$

Both Hudibras and the Tatler, however, were preceded by a lesserknown depiction of Tagliacotian rhinoplasty in which the socio-politics of the body were sharply apparent. In the I630s, William Davenant, poet laureate, lost his nose to syphilis. In the I640s or ' 50 , Hester Pulter, whom Marcus Nevitt affirms had never met Davenant, wrote a poem in which she humorously proposed to donate some of her own flesh to replace the missing member. ${ }^{9 \mathrm{I}}$ She would, she argues, give her nose, were it not for the fact that she would then be supposed to have suffered the effects of venereal disease:

For who but that bright Eye above

Would know 'twere charity, not love?

Then Sir, your pardon must I beg -

Excuse my nose: accept my leg!

${ }^{88}$ Alanna Skuse, "Keep your Face out of my Way or I'll Bite off your Nose”: Homoplastics, Sympathy, and the Noble Body in the Tatler, I710', Journal for Early Modern Cultural Studies I7:4 (2018): II 3-32.

89 Samuel Butler, Hudibras (London: John Murray, I 835 ).

90 Jonathan Swift, The Complete Poems, ed. Pat Rogers (London: Penguin, I983), p. 448; Edward Ward, The Second Part of the London Clubs; Containing, the No-Nose Club, the Beaus Club, the Farting Club, the Sodomites, or Mollies Club, The Quacks Club (London: printed by J. Dutton, 1709).

9I As I describe below, there is some confusion around the date of this poem's composition (Marcus Nevitt, 'The Insults of Defeat: Royalist Responses to Sir William Davenant's Gondibert [165 I]', The Seventeenth Century 24:2 [October 2009]: 287). 
But yet, be sure, both night and day,

For me as for yourself you pray.

For if I first should chance to go

To visit those sad shades below

As my frail flesh there putrifies,

Your nose, no doubt, will sympathize. ${ }^{92}$

Pulter's poem demonstrates that the humorous potential of the Tagliacotian operation was recognised long before Hudibras. Furthermore, this humour assumed that the poem's audience had at least some notion of physiological sympathy and why it might cause a grafted nose to drop off with the original owner's death. The image Pulter presents of offering up her flesh, which may later die on the face of the recipient, is both grotesque and bizarrely erotic. Any man, Pulter asserts, 'Would give his nose, to have yo' wit'. However, Pulter is self-evidently already a witty woman, and the imagined donation is more visceral than cerebral, tying the fates of their two bodies together.

The picture is complicated further by the sensory implications of receiving a new nose. Given that the olfactory bulb is located within the skull, recipients of a nose graft (as well as those with missing noses) could presumably still smell. Thus in Addison's satire on nose transplantation and sympathy, he imagined that 'if anything went amiss with the nose, the porter felt the effects of it', such that if the recipient should 'smell pepper, or eat mustard ... the [donor] part where the incision had been made was seized with unspeakable twinges and prickings'..$^{33}$ Where one portion of flesh can stand in for another, so haptic sensations (pricking) can 'anagrammatise' for olfactory ones, just as Bulwer later proposed when he extolled the usefulness of sign language for the deaf. ${ }^{94}$ It is unclear whether Pulter similarly envisions a tactile kick-back from Davenant's sense of smell, but the sympathetic link between the two parties now entwines their sensory landscapes. Thus, the speaker's concern about the social inadvisability of sacrificing her own nose deliberately misses the point: joining the flesh of one person to that of another is an innately intimate act, which is the more easily read as sexual because Davenant is already marked by sexual vice. Neither are Davenant's indiscretions assumed to be behind him. If and when Cupid strikes again, warns Pulter, 'Then the next

\footnotetext{
${ }^{2}$ Hester Pulter, 'To Sir W.D. upon the Unspeakable Loss of the Most Conspicuous and Chief Ornament of His Frontispiece', in Women's Works: I625-I650, ed. Donald W. Foster and Tobian Banton, Ist edition (New York: Wicked Good Books, 2013), pp. I60-I.

93 Joseph Addison, 'Non Cuicunque Datum Est Habere Nasum', Tatler, I 7 Io.

94 Bearden, 'Before Normal, There Was Natural'.
} 
loss will be your brain'. To lose one nose, it seems, is unfortunate; to lose another implies a level of carelessness which even this sympathetic author cannot excuse:

\section{Prodigious the knight remains,}

Without or nose, or fame, or brains.

Then a bold ordnance struck the title off?

Thus the proud Parcae sit and at us scoff.

What now remains - the man, at least?

No, surely: nothing left, but beast.

Then royal favour glued it on again,

And now the knight is bow-dyed and in grain.

Then trample not that honor in the dust

In being slaves to those are slaves to lust. ${ }^{95}$

Pulter's tone is relatively gentle here. As a confirmed Royalist, she and Davenant were - politically at least - on the same side. Cock thus reads this poem principally as an exercise in aristocratic beneficence 'bequeathed from a position of privilege', albeit one with strings attached. ${ }^{96}$ In imagining a sympathetic bond between their two bodies, Pulter places herself in the thick of the Royalist campaign by proxy: 'through the logic of the transplant, Pulter's private body is brought into public politics and the masculine spaces of war'.$^{97}$ Moreover, Pulter's argument reveals something about the way in which bodily integrity became particularly important in periods of socio-political unrest. There is much uncertainty about the dates of Davenant's losing his nose and of Pulter's composing the above poem. The editors of Women's Works: I625-I650 put the former at I638 and the latter soon after in I643. Mary Edmond believes Davenant to have contracted syphilis in 1630 and to have become disfigured by $1634 .{ }^{98}$ Nevitt argues that Davenant lost his nose sometime in the 1630 and Pulter wrote about it in the 165 os. $^{99}$ Despite these differences, it is apparent that Pulter was not alone in drawing attention to Davenant's altered face; indeed, her rhetoric had much in common with Davenant's Cromwellian detractors. Nevitt has described how Davenant's missing nose became for his enemies 'synecdochic of the vanishing pleasures

95 Pulter, 'To Sir W.D. upon the Unspeakable Loss of the Most Conspicuous and Chief Ornament of His Frontispiece'.

96 Cock, Rhinoplasty and the Nose, p. $220 . \quad 97$ Ibid., p. 222.

$9^{8}$ Mary Edmond, Rare Sir William Davenant: Poet Laureate, Playwright, Civil War General, Restoration Theatre Manager (Manchester: Manchester University Press, 1987), pp. 44-5.

99 Nevitt, 'The Insults of Defeat', 287. 
(riotously convivial, unashamedly sexual) of Caroline England'. ${ }^{\text {oo }}$ Such jibes had particular bite because, as Covington describes, some Royalists embraced facial wounds as signs of valorous conduct, attained in faceto-face combat. ${ }^{\text {IOI }}$ Davenant's facial difference suffered even more by comparison, and may have undercut the chivalric ideals of his unfinished epic Gondibert (1650-2). For Pulter, Davenant's loss threatens the idea of the noble body. Without the redeeming factor of gentility, Davenant's sexual appetites render him positively sub-human, a 'beast' or 'slave'. 'Royal favour' - that is, the knighthood Davenant received in I643 may transform the way in which Davenant's past indiscretions are viewed, giving them a new 'dye'. In order for the dye to prove itself truly 'in grain', however, it is necessary that the newly ennobled Davenant perform nobility with his body, despite its shortcomings.

Read in this context, Pulter's treatment of Davenant's nose is entirely consistent with Alice Eardley's contention that 'Pulter holds men primarily responsible for the nation's political disintegration and for the widespread social and moral collapse with which that disintegration is associated. ${ }^{\text {'O2 }}$ Moreover, Pulter's emphasis on Davenant's moral shortcomings and her strangely salacious suggestion of a sympathetic graft between their bodies need not be discordant. Well acquainted with the latest scientific developments, Pulter saw that allografting and other transformative surgeries called into doubt the connection between body, character, and innate abilities. In so doing, new science had the potential to undermine the naturalness of the noble body, a belief upon which the King's right to rule was partly based. Pulter's exhortation to Davenant is thus timely. If one's claim to socio-political superiority is based upon a monist conception of self of which the body is an intrinsic part, it is perilous to undermine that conception by making one's body look decidedly ignoble. Rather, the connection must go both ways: as one's rank ennobles one's body, so one's body, and its appetites and behaviours, must come into line with one's social responsibilities.

Iоo Ibid., 297. Conversely, Cock notes that Cromwell's large red nose was a common target of ridicule among his enemies, and the nose was torn off his funeral effigy during its lying in state at Somerset House (Cock, Rhinoplasty and the Nose, p. 2 I 8 ).

ro Covington, Wounds, Flesh and Metaphor, pp. 96-7.

${ }_{102}$ Hester Pulter, Poems, Emblems, and The Unfortunate Florinda, ed. Alice Eardley (Toronto: Iter, 20I4), p. 3. 


\section{Conclusion}

At the beginning of this chapter, we saw how one's face might be one's fortune in early modern society. It was also the part of the body on which misfortunes were most clearly displayed - maims associated with illness and injury, teeth lost through age and poverty or regained through wealth, and, most shamefully, noses sacrificed to venereal disease. The face was likewise the location of many sensory organs, and damage to the face thus affected the texture of one's everyday life in a profound way, influencing what one did or did not taste, smell, see, and feel.

For these reasons, medical and cosmetic interventions to the face captured the imagination of medical practitioners, writers, and thinkers. The possibilities offered by transplanted teeth and grafted noses were an imaginatively stimulating means of thinking about the question of how intrinsically one's own flesh 'belonged' to oneself. Was it possible, for example, that a transplanted piece of flesh would react to the illnesses and injuries of its original owner, as proponents of sympathy suggested? This idea may have seemed as far-fetched to most early modern people as it does to modern readers. However, its popularity as a tool for thought reiterates how far authors and readers of the seventeenth and eighteenth centuries were interested in considering the nature of embodiment, from both philosophical and scientific perspectives. In some respects, scientific exercises such as allografting and blood transfusions implied that the flesh was merely matter, to be exchanged and manipulated as it suited the person 'inside'. At the same time, however, even satirical representations of these fleshly additions recognised that there was nothing superficial about changing the exterior of a person. To alter the face in particular was to reshape a person's social and sensory encounters with the world, and thus to alter their lived experience. 